El-Kassaby, Y. A., D. G. W. Edward and D. W. Taylor (1992): Genetic control of germination parameters in Douglas-fir and its importance for domestication. Silvae Genet. 41(1): 48-54.

Hawkins, C. D. B. (1998): Interactions of Forest seedling Nurseries and Seed Orchards. In: Tree Improvement: Applied Research and Technology Transfer, Sunilpuri (ed.), Oxford and IBH publishing Co. Pvt. Ltd. pp 126-139.

HoodA, M. S. and R. BAHADUR (1993): Variability, correlation and path co-efficient analyses for some seed traits in Subabul (Leucaena leucocephala L.). Seed Research 21(1): 49-51.

IndiRA, E. P., S. Chand BASHA and K. C. CHACKo (2000): Effect of seed size grading on the germination and growth of teak (Tectona grandis) seedlings. Journal of Tropical Forest Science 12(1): 21-27.

International Seed Testing Association (1993): International rules for seed Testing 1993. Seed Sci. Technol. 21 suppliment, Zurich, Switzerland, 288 p.

Johnsen, O., J. Dietrichson and G. Skaret (1989): Phenotypic changes in progenies of northern clones of Picea abies (L.) Karst. grown in a southern seed orchard. III. Climate changes and growth in a progeny trial. Scand. J. For. Res. 4: 343-350.

Jyothi, P. V., J. B. Atluri and C. Subba Reddi (1991): Pollination ecology of Santalum album (Santalaceae). Tropical Eco. 32: 98-104.

Long, E. M. and B. A. Peoples (1991): Nursery management and tree improvement. In: Nursery Management Workshop Proc., Texas, A. and M. Univ. Austin, TX, Texas For. Serv. Publ. No. 148 pp 119-126.

NaGaveni, H. C. and H. S. Ananthapadmanabha (1986): Seed polymorphism and germination in Santalum album L. Van Vigyan 24: 25-28.

PERRY, T. O. and W. L. HAFLEY (1981): Variation in seedling growth rates: their genetic and physiological basis. In: Proc, $16^{\text {th }}$ S. For. Tree improve. Conf., Blacksburg, V.A, May 26-29, 1981 Athens, GA, USDA-USFS, For. Sci. Lab. pp 200-204.

Phanse, V .G. and P. V. Sukhatme (eds.). (1978): Statistical methods of agricultural workers. ICAR Pub. New Delhi, pp. 327.

Reich, P. B., J. Oleksyn and M. G. TJoelker (1994): Seed mass effects on germination and growth of diverse European Scots pine population. Canadian Journal of Forest Research 24: 306-320.

SRImathi, R. A., H. D. Kulkarni and K. R. Venkatesan (1995): Recent advances in Research and Management of Sandal (Santalum album L.) in India. SRIMATHI, R. A., H. D. Kulkarni and Venkatesan, K. R. (eds.) Published by the Associated Publishing Company, New Delhi. P416.

SRInivasan, V. V., V. R. Sivaramakrishnan, C. R. RANGasWAMy, H. S. ANANTHAPADMANABHa and K. H. SHANKARANARAYANA (1992): Sandal (Santalum album L.). Published by the Director, Institute of Wood Science and Technology (ICFRE), Bangalore, pp 233.

Toon, P. G., Haines, R. J. and Dieters, M. J. (1991): Relationship between seed weight, germination time and seedling height growth in Pinus caribaea Morlet var. hondurensis Barret and Golfari. Seed Sci. \& Tech. 19(2): 397-402.

Veerendra, H. C. S. and H. S. A. Padmanabha (1996): The breeding system in sandal (Santalum album L.) Silvae Genet. 45(4): 188-190.

VEerendRA, H. C. S. and C. R. SARMA (1990): Variation studies in sandal (Santalum album L.): 1. Time of emergence and seedling vigour. Ind. Forstr. 119(7): 568-571.

Veerendra, H. C. S., S. Ramalakshmi and B. B. MalleSHA (1999): Variation in seed characterstics in provenances of sandal (Santalum album L.). Ind Forstr. 125(3): 308-312.

\title{
Genetic Variation of Physical and Chemical Wood Properties of Eucalyptus globulus
}

\author{
By L. A. ApiolazA ${ }^{1), 2)}$, C. A. RAYMOND ${ }^{3)}$ and B. J. YeO ${ }^{1)}$
}

(Received $3^{\text {rd }}$ November 2004)

\begin{abstract}
This study considered the degree of genetic variation for diameter $(\mathrm{DBH})$, basic density (BD), predicted pulp yield (PPY), fibre length (FL), microfibril angle (MFA) and cellulose content (CC) amongst eight subraces of Eucalyptus globulus growing in a field trial in NW Tasmania. There were significant subrace effects for BD, FL

1) Forestry Tasmania, GPO Box 207, Hobart Tas 7001, Australia.

2) CRC for Sustainable Production Forestry and School of Plant Science, Private Bag 55, Hobart Tas 7001, Australia.

$\left.{ }^{3}\right)$ State Forests New South Wales, P.O. Box 46 Tumut NSW 2720, Australia. Email: Luis.Apiolaza@forestrytas.com.au, Phone: +61-3-6233 8127.
\end{abstract}

and CC. This variation affected the relative profitability of the subraces for pulp production. On average, the most profitable subraces (on NPV/ha over the base population mean) were Strzelecki Ranges (\$862.04), Western Otways $(\$ 657.80)$ and Strzelecki Foothills (\$576.81). The genetic control (heritability) of variation in DBH, FL and MFA was moderate $\left(0.15<\mathrm{h}^{2}<0.27\right)$, while control for BD, PPY and CC was high $\left(\mathrm{h}^{2}>0.40\right)$. Genetic correlations between growth and wood properties were not statistically significant, except for DBHMFA (-0.86). Most genetic correlations amongst wood properties were outside the parametric space $(<-1$ or $>1$ ), but there were significant correlations between BDMFA (-0.70) and PPY-CC (0.82). The empirical response 
to selection on an index based on a pulp wood objective (which included volume and basic density) resulted in a gain of $4.3 \%$ for $\mathrm{DBH}, 7.9 \%$ for $\mathrm{BD}$ and marginal changes for all other traits, with a net impact in profit of $\$ 1,270 /$ ha. However, future profit calculations will need to consider the effect of FL, MFA and CC on the economics of wood processing to fully evaluate the economic impact of breeding.

Key words: BLUP, racial variation, heritability, genetic correlations, breeding, profit.

\section{Introduction}

Eucalyptus globulus Labill is the foremost pulpwood eucalypt in temperate regions, and it is widely planted in Spain, Portugal, Chile, Australia and South Africa, with an estimated total estate of over 2 million ha (Doughty, 2000; PотTs et al., 2004). Previous research has shown that there is considerable genetic variation in $E$. globulus for multiple traits (e.g., DuTKOWSKI and PoTTS, 1999), and wood properties are no exception (Muneri and RAYMOND, 2000; MirANDA et al., 2001a; MiRANDA et al., 2001b). Furthermore, considerable gain for commercial plantations can be obtained exploiting the genetic variation within natural populations of $E$. globulus.

Tree breeding has evolved simultaneously with the forest industry. Breeding programs have progressed from improving mostly growth and form (e.g., THULIN, 1957; BANNISTER, 1959) to tailoring genetic material towards end-products requirements (e.g., BORRALHO et al., 1993; Greaves et al., 1997; ApIOLAZA and GARRICK, 2001). The direction of genetic progress for a breeding program is dictated by its breeding objective; i.e., by the linear combination of traits and their relative economic importance (HAZEL, 1943; PONZONI, 1986; GoDDARD, 1998). The current breeding objective for Eucalyptus globulus in Australia includes volume (VOL $\left[\mathrm{m}^{3} / \mathrm{ha}\right]$ ), basic density (BD $\left[\mathrm{kg} / \mathrm{m}^{3}\right]$ ) and pulp yield (PY [\%]), where all traits are considered at rotation age. This objective is based on economic modelling of a vertically integrated pulp production industry (GREAVES et al., 1997).

Breeding objectives are periodically updated, reflecting changing economic circumstances, new knowledge about industrial processes and incorporation of additional industrial systems to be served by material from the breeding program (APIOLAZA and GREAVES, 2001). Additional processes under consideration for E. globulus are paper production, sawn timber, veneers and reconstituted wood. The closer one gets to final products, the greater the influence of wood properties on the economics of the process (RAYMOND and APIOLAZA, 2004). There are many other wood properties that either provide extra information on objective traits (i.e., may act as selection criteria) or influence products not considered by the current breeding objective. Cellulose content (CC [\%]), calculated as grams of cellulose per mass of wood, is considered to be a reliable predictor of pulp yield in E. nitens (KuBE et al., 2001; RAYMOND and SCHIMLECK, 2002). Microfibril angle (MFA [degrees]) measures the angle of the miscelles (aggregations of microfibrils) with respect to the longitudinal access of the cells. The smaller the angle the greater the tensile strength of the fibre and the smaller its shrinkage (Bootle, 1983). Fibre length (FL $[\mathrm{mm}]$ ) measures the total length of wood fibres, which represent $66 \%$ of the wood tissue (MIRANDA et al., 2001a). In general terms, final users will want to increase VOL, BD, PY and CC, and to reduce MFA ( Dr Bruce Greaves, personal communication). These traits may be either included in alternative objectives, or to be considered in the deployment phase objective. The latter is an objective used only for the production populations (e.g. seed orchards or clonal propagation systems), which includes extra traits as well as non-additive genetic effects.

The objective of this project is to provide insights on the degree of variation amongst natural populations of $E$. globulus for physical (basic wood density, fibre length, and micro fibril angle) and chemical (pulp yield and cellulose content) wood properties and their relationship with growth. This research also offers a first approximation for the degree of additive genetic control (heritability), the genetic association (genetic correlations) between these traits and the expected response to selection.

\section{Materials and Methods}

The study was based on an open pollinated progeny test at West Ridgley in North Western Tasmania (for details see MACDONALD et al., 1997). The trial was established in 1989 and included families from the CSIRO 1987-88 base population collection. The test has an incomplete block design, with 451 families in 5 replicates, with 17 incomplete blocks each, using two-tree row plots. Although West Ridgley contains material from 22 subraces, sampling focused on eight subraces (as defined by DutKowski and PotTs, 1999) already sampled for wood density and growth in trials at Massy Greene, Mt Worth and Flynn (MUNERI and RAYMOND, 2000).

In 2000, all 2662 surviving trees were assessed for diameter over bark (DBH $[\mathrm{cm}])$ and 188 trees were sampled for wood properties. The latter represented 35 families from 8 subraces, choosing mostly one, and only a few times two, tree per plot. Three increment cores (at around $1.1 \mathrm{~m}$ height) were taken from each tree. The first one was used to estimate basic density using the water displacement method. This core was then macerated to determine average core fibre length (FL [mm]). The second core was analysed to determine pith to bark variation for density and microfibril angle (MFA [degrees]) using SilviScan (Evans et al., 2000). The third core was used to estimate predicted pulp yield (PPY [\%]) using Near Infra-Red Analysis (NIRA) and cellulose content (CC [\%]) from a laboratory digest (RAYMOND and SCHIMLECK, 2002).

The most generic model equation used in the trial was:

$$
\boldsymbol{y}=X f+Z_{1} b+Z_{2} p+Z_{3} a+e
$$

Equation 1

where $\boldsymbol{y}$ is the vector of phenotypic observations, $\boldsymbol{f}$ is the vector of fixed effects (subrace and replicate), $\boldsymbol{b}$ is the 
vector of random incomplete block effects, $\boldsymbol{p}$ is the random vector of plot effects, $\boldsymbol{a}$ is the vector of random additive genetic effects and e is the vector of random residuals (environmental and non-additive effects). $\boldsymbol{X}, \boldsymbol{Z}_{1}, \boldsymbol{Z}_{2}$ and $\boldsymbol{Z}_{\mathbf{3}}$ are design matrices linking the phenotypic observations with the fixed and random effects.

The expected value and dispersion matrices, assuming a multivariate normal distribution (MVN) are:

$$
\left[\begin{array}{c}
y \\
b \\
p \\
a \\
e
\end{array}\right] \sim M V N\left(\left[\begin{array}{c}
X f \\
0 \\
0 \\
0 \\
0
\end{array}\right],\left[\begin{array}{ccccc}
V & Z_{1} B & Z_{2} P & Z_{3} G & R \\
B Z_{1}^{\prime} & B & 0 & 0 & 0 \\
P Z_{2}^{\prime} & 0 & P_{0} & 0 & 0 \\
G Z_{3}^{\prime} & 0 & 0 & G & 0 \\
R & 0 & 0 & 0 & R
\end{array}\right]\right)
$$

Equation 2

where $\boldsymbol{B}=\sigma_{\mathrm{b}}^{2} \boldsymbol{I}, \boldsymbol{P}=\sigma_{\mathrm{p}}^{2} \boldsymbol{I}, \boldsymbol{G}=\sigma_{\mathrm{a}}^{2} \boldsymbol{A}$ and $\boldsymbol{R}=\sigma_{\mathrm{e}}^{2} \boldsymbol{I}, \boldsymbol{I}$ is an identity matrix, $\boldsymbol{O}$ is a null matrix and $\boldsymbol{A}$ is the numerator relationship matrix for the trees. In addition, $\sigma_{\mathrm{b}}{ }^{2}$ is the incomplete block variance, $\sigma_{\mathrm{p}}{ }^{2}$ is the plot variance (only fitted for $\mathrm{DBH}$ ), $\sigma_{\mathrm{a}}{ }^{2}$ is the additive genetic variance and $\sigma_{\mathrm{e}}^{2}$ is the residuals variance. The $\boldsymbol{A}$ matrix was modified to take into account $30 \%$ average selfing in E. globulus (DuTKowsKi et al., 2001).

This model was fitted for each trait using ASReml (GILMOUR et al., 2002), testing significance of both fixed effects with a Wald test, and random effects using a Likelihood Ratio Test (LRT). The analyses of all traits started with the full model equation, but the final model was fitted after dropping non-significant random effects (Table 1).

Table 1. - Factors included in the analysis and number of observations for each trait. An $\mathrm{x}$ indicates the inclusion of the factor in the final model for a trait. The number of observations for wood properties varies because of problems processing a few wood cores.

\begin{tabular}{lllllll}
\hline Trait & N & rep & subrace & iblock & plot & tree \\
\hline DBH & 2662 & $\mathrm{x}$ & $\mathrm{x}$ & $\mathrm{x}$ & & $\mathrm{x}$ \\
BD & 188 & $\mathrm{x}$ & $\mathrm{x}$ & & $\mathrm{x}$ \\
PPY & 184 & $\mathrm{x}$ & $\mathrm{x}$ & & $\mathrm{x}$ \\
FL & 169 & $\mathrm{x}$ & $\mathrm{x}$ & & $\mathrm{x}$ \\
MFA & 173 & $\mathrm{x}$ & $\mathrm{x}$ & & $\mathrm{x}$ \\
CC & 184 & $\mathrm{x}$ & $\mathrm{x}$ & & $\mathrm{x}$ \\
\hline
\end{tabular}

The heritability $\left(\mathrm{h}^{2}\right)$, or degree of additive genetic control, was calculated for each trait using:

$$
h^{2}=\frac{\sigma_{a}^{2}}{\left(\sigma_{a}^{2}+\sigma_{e}^{2}\right)}
$$

This assumes that predicted breeding values are adjusted by replicate, subrace and incomplete block before selection.

Additive genetic covariance components $\left(\sigma_{\mathrm{a}_{12}}\right)$ and genetic correlations $\left(r_{g}\right)$ between two traits were obtained from bivariate analyses:

$$
r_{g}=\frac{\sigma_{a_{12}}}{\sqrt{\sigma_{a_{1}}^{2} \sigma_{a_{2}}^{2}}}
$$

where $\sigma_{\mathrm{a}_{1}}^{2}$ and $\sigma_{\mathrm{a}_{2}}^{2}$ are the additive genetic variances for traits 1 and 2. Bivariate models extend equations 1 and 2 , where each of the vectors now contains values for two traits and the covariance matrices are $\boldsymbol{B}=\Sigma_{\oplus} \boldsymbol{B}_{0}, \boldsymbol{P}=$ $\Sigma_{\oplus} \boldsymbol{P}_{0}, \boldsymbol{G}=\boldsymbol{A} \otimes \boldsymbol{G}_{0}$, and $\boldsymbol{R}=\Sigma_{\oplus} \boldsymbol{R}_{0}$. Now $\boldsymbol{B}_{0}, \boldsymbol{P}_{0}, \boldsymbol{G}_{0}$ and $\boldsymbol{R}_{0}$ are matrices of dimension $2 \times 2$ containing the variances for each trait and the covariance between traits; $\Sigma_{\oplus}$ and $\otimes$ are the direct sum and direct product operations respectively.

While the current $E$. globulus breeding objective traits includes volume, basic density and pulp yield, selection is currently carried out based on stem diameter and core basic density (KERR et al., 2002). A selection index I [\$/ha] was obtained maximising the correlation between selection criteria and genetic-economic value using:

$$
I=\boldsymbol{G}_{s s}{ }^{-1} \boldsymbol{G}_{s o} \boldsymbol{w}
$$

where $\boldsymbol{G}_{s s}$ and $\boldsymbol{G}_{s o}$ are the additive genetic covariance matrices for selection criteria (DBH and core $\mathrm{BD}$ ), and between selection criteria and objective traits (VOL, BD and PY) respectively, and $\boldsymbol{w}$ is the vector of economic weights (see Table 2) estimated by GrEAVEs et al. (1997). The overall breeding values used in the calculations included both subrace effects and additive genetic effects.

In principle, it is possible to estimate algebraically the correlated response to selection on $I$ for non-objective traits (FL, MFA and CC). However, given the low precision of the estimated genetic correlations (see results and discussion section), it was preferred to obtain an empirical response to selection as the difference between the population mean and the top $10 \%$ based on index value.

\section{Results and Discussion}

\section{Subrace differences}

Differences between subraces means were significant for BD, FL and CC (see Table 3). The magnitude of the differences between the best and worst subrace can be as high as $33 \%$ for growth (DBH), $15 \%$ for physical (FL and MFA) and $9 \%$ for chemical (CC) wood properties. In terms of average pulp productivity (BD*PPY in $\mathrm{kg}$ pulp $/ \mathrm{m}^{3}$ ), Strzelecki Ranges is the best, while King Island is the worst subrace, mostly reflecting differences on BD. However, King Island can partially compensate for this with additional growth, making it on average the third highest producer of pulp per ha (Results not shown). The subrace rankings for $\mathrm{BD}$ are similar to those presented by (MUNERI and RAYMOND, 2000), while the significant differences for FL are consistent with the findings of Miranda et al. (2001a).

Figure 1 presents the subrace distribution of economic values for individual trees, which summarises the breeding values for DBH, BD and PPY. During the early 1990s planting of King Island stock in Australia was quite popular due to its higher growth rate; however, concerns about its low basic density prompted industry to switch to mainland stock (mostly from the Strzelecki and Otways areas; Роттs et al., 1999). It is clear that, in financial terms, the superiority of Strzelecki Foothills, Strzelecki Ranges and Eastern Otways for a pulp wood breeding objective at the West Ridgley site is consistent with that decision. When selecting the top $10 \%$ of trees (22 out of 224 including parents and progenies), which is 
Table 2. - Additive genetic variances $\left(\sigma_{a}^{2}\right)$, genetic correlations $\left(r_{g}\right)$ and economic weights $(\mathrm{w})$ used for the construction of the selection index.

\begin{tabular}{|c|c|c|c|c|c|c|c|c|}
\hline & \multirow[b]{2}{*}{ Unit } & \multirow[b]{2}{*}{$\sigma_{a}^{2}$} & \multirow[b]{2}{*}{ w } & \multicolumn{5}{|c|}{ Correlations $\left(r_{g}\right)$} \\
\hline & & & & DBH & core BD & VOL & $\mathrm{BD}$ & PY \\
\hline$\overline{\mathrm{DBH}}$ & $\mathrm{Cm}$ & 5.15 & & 1 & $\overline{0}$ & 0.95 & 0 & 0 \\
\hline core BD & $\mathrm{kg} / \mathrm{m}^{3}$ & 516.63 & & 0 & 1 & 0 & 1 & 0.15 \\
\hline VOL & $\mathrm{m}^{3} / \mathrm{ha}$ & 3183.86 & 12.56 & & & & & \\
\hline $\mathrm{BD}$ & $\mathrm{kg} / \mathrm{m}^{3}$ & 516.63 & 23.77 & & & & & \\
\hline PY & $\%$ & 1.057 & 279.59 & & & & & \\
\hline
\end{tabular}

Table 3. - Subrace means for diameter at breast height (DBH), basic density (BD), predicted pulp yield (PPY), fibre length (FL), microfibril angle (MFA), cellulose content (CC) and index value (I). There are significant $(\mathrm{P}<0.05)$ differences between subraces for $\mathrm{BD}, \mathrm{FL}$ and $\mathrm{CC}^{\S}$. All traits were assessed at age 11 years.

\begin{tabular}{|c|c|c|c|c|c|c|c|c|c|c|c|c|c|}
\hline Subrace & DB & & BD $(k$ & on) & PPY & & & m) & MFA & $\mathrm{CC}$ & & I (\$N) & V/ha) \\
\hline King Island & 24.27 & a & 458.86 & $\mathrm{c}$ & 51.75 & a & 0.74 & $a b$ & 15.93 & a 42.20 & $a b$ & -231.16 & $\overline{b c}$ \\
\hline Southern Tasmania & 20.76 & a & 486.54 & $a b c$ & 52.04 & a & 0.81 & $\mathrm{a}$ & 17.95 & a 42.78 & a & -160.74 & $\mathrm{~b}$ \\
\hline South-Eastern Tasmania & 20.27 & a & 484.49 & $b c$ & 51.96 & a & 0.75 & $a b$ & 18.83 & a 41.89 & $a b$ & -671.88 & $\mathrm{c}$ \\
\hline North-Eastern Tasmania & 18.21 & a & 486.26 & $a b c$ & 50.51 & a & 0.68 & $b$ & 19.55 & a 40.19 & $\mathrm{~b}$ & -1267.41 & d \\
\hline Flinders Island & 21.08 & a & 485.22 & $a b c$ & 50.98 & a & 0.74 & $a b$ & 16.28 & a 41.89 & $a b$ & -163.88 & b \\
\hline Strzelecki Foothills & 21.24 & a & 518.67 & $a b$ & 50.79 & a & 0.78 & $a b$ & 16.02 & a 41.84 & $a b$ & 576.81 & a \\
\hline Strzelecki Ranges & 20.62 & a & 531.90 & a & 51.29 & a & 0.75 & $a b$ & 17.15 & a 42.19 & $a b$ & 862.04 & a \\
\hline Western Otways & 23.07 & a & 495.33 & $a b c$ & 52.21 & a & 0.78 & $\mathrm{a}$ & 17.06 & a 43.39 & a & 657.80 & a \\
\hline Overall mean & 21.53 & & 491.60 & & 51.57 & & 0.76 & & 17.21 & 42.20 & & 0 & \\
\hline
\end{tabular}

$\S$ Same letter within a trait indicates that subraces are not significantly different at $\alpha=0.05$.

a common sampling intensity in breeding programs, only four subraces are represented: Strzelecki Ranges (12 trees), Western Otways (6 trees), Strzelecki Foothills (3 trees) and King Island (1 tree).

Nevertheless, it is important to highlight that subrace profitability will depend on the industrial process tailored by the breeding program. There are indications that $E$. globulus solid wood products may benefit of lower wood density (making drying the wood easier); a situation that could favour subraces like King Island (Peter Volker, personal communication).

\section{Genetic parameters}

Estimated genetic parameters are presented in Table 4. Heritabilities were low to moderate for DBH, FL and MFA (but not significantly different from zero for the last two), and high for BD, PPY and CC. Genetic parameters for $\mathrm{DBH}$ and $\mathrm{BD}$ are in the range of those previously published elsewhere (e.g., MUNERI and RAYMOND, 2000). The genetic correlations are associated with very large standard errors. Genetic correlations between growth $(\mathrm{DBH})$ and all wood properties were non-significantly different from zero, except for DBH-MFA $\left(r_{g}=\right.$ -0.86). There were high significant correlations for BDCC $\left(r_{g}=0.61\right)$ and PPY-CC $\left(r_{g}=0.82\right)$. The correlation BD-MFA was non-significant, while estimates for correlations BD-PPY, BD-FL, PPY-FL, PPY-MFA, FL-MFA and MFA-CC were outside the parameter space (although tested significant), probably due to the small sample size for wood properties (see Table 1). Figure 2 presents a scatter matrix of the overall breeding values for all individuals with wood property measurements, predicted using univariate analyses and accounting for subrace differences. The scatter matrix confirms the results for the significant genetic correlations (BD-CC and PPY-CC), with the slopes of the linear regressions being close to the correlation values. However, it does not support the high values of genetic correlations outside the parameter space, indicating potential convergence problems in the analyses for those traits.

The level of additive genetic variation in the population is presented as the coefficient of variation (Table 4),

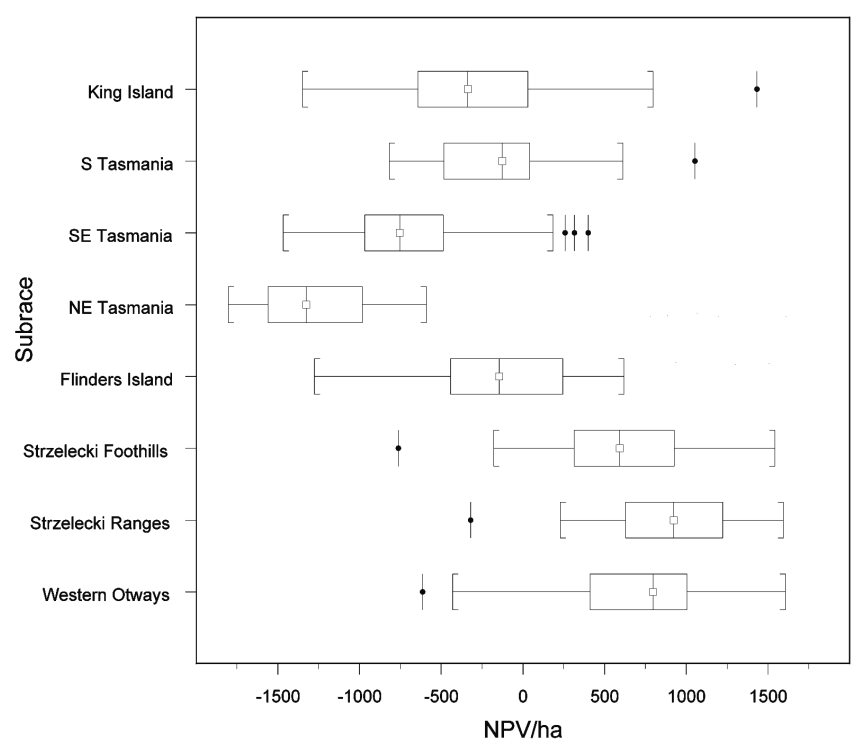

Figure 1. - Distribution of economic values in each subrace. The box plots display the median value $(-\square-)$, interquartile range (IQR, the box), values no more than $1.5 \mathrm{IQR}$ beyond the quartiles (vertical lines) and outliers (-•-) for each subrace. 
to allow comparisons between traits. There is more additive variation to be exploited within subraces for growth $(11 \%)$ than for wood properties $(<9 \%)$. Despite this, given the higher heritabilities for wood properties, similar responses to selection would be expected for both growth and wood properties.

There is evidence suggesting that genetic parameters for growth traits are upwardly biased for open pollinated E. globulus (Роттs et al., 1995). Although the numerator relationship matrix was modified to account for an average selfing, there is variation from family to family on selfing rates or inbreeding depression levels likely to affect the estimates, thus the correction is only an approximation (BORRALHO, 1994; HARDNER et al., 1996).

\section{Response to selection}

Table 5 shows the effect of selection on the selection index:

$$
I=296.68 B V_{D B H}+25.67 B V_{B D}
$$

where $B V_{D B H}$ and $B V_{B D}$ refer to the overall (including subrace effects) breeding values for $\mathrm{DBH}$ and $\mathrm{BD}$ respectively. This index emphasises basic density, with an empirical gain of $7.9 \%$ on basic density, $4.3 \%$ on

Table 4. - Heritabilities (bold diagonal), genetic correlations between traits (below diagonal) and additive coefficients of variation (last column). Standard errors are between parentheses.

\begin{tabular}{|c|c|c|c|c|c|c|c|}
\hline & DBH & BD & PPY & FL & MFA & $\mathrm{CC}$ & AddCV \\
\hline DBH & $\mathbf{0 . 2 0}(0.04)$ & & & & & & 11.19 \\
\hline BD & $-0.58^{\dagger}(0.44)$ & $\mathbf{0 . 4 4}(0.22)$ & & & & & 4.67 \\
\hline PPY & $-0.16^{\dagger}(0.48)$ & $1.08^{\S}(0.24)$ & $\mathbf{0 . 4 3}(0.22)$ & & & & 2.04 \\
\hline FL & $-0.02^{\dagger}(0.57)$ & $1.21^{\S}(0.58)$ & $1.03^{\S}(0.28)$ & $\mathbf{0 . 1 6 ^ { \dagger }}(0.17)$ & & & 3.74 \\
\hline MFA & $-0.86(0.40)$ & $-0.70^{\dagger}(0.41)$ & $-1.11^{\S}(0.34)$ & $-1.11^{\S}(0.41)$ & $\mathbf{0 . 2 7 ^ { \dagger }}(0.24)$ & & 8.36 \\
\hline $\mathrm{CC}$ & $0.61^{\dagger}(0.34)$ & $0.61(0.25)$ & $0.82(0.11)$ & $1.12^{\S}(0.22)$ & $-1.10^{\S}(0.27)$ & $\mathbf{0 . 8 4}(0.27)$ & 2.99 \\
\hline
\end{tabular}

${ }^{\dagger}$ Parameter is not significant using a Likelihood Ratio Test $(\mathrm{P}>0.05)$.

$\S$ Correlation is outside the parameter space. Sample size is too small to determine an accurate value.

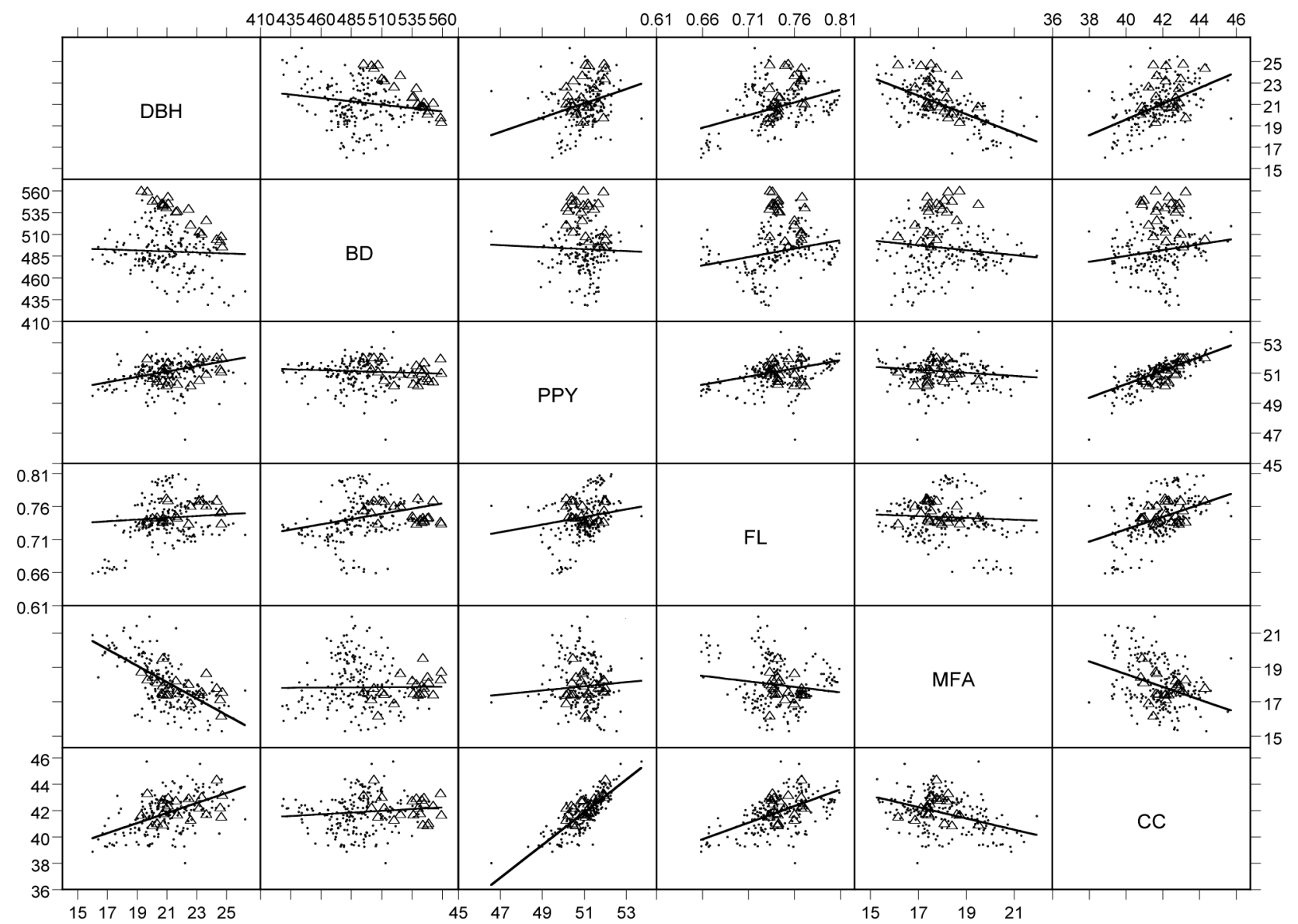

Figure 2. - Scatter matrix of overall breeding values (including subrace effects) for the traits under analysis. Triangles depict the top $10 \%$ of individuals for the selection index and lines provide an indication of correlation between traits. Selected trees are mostly in the centre of the distributions of PPY, FL, MFA and CC, confirming the small responses to selection for those traits. 
Table 5. - Complete and selected population breeding value means. Absolute gain is the difference between complete and selected means. Profit per ha is expressed as difference from the complete population mean.

\begin{tabular}{llllllll}
\hline & Traits & \multicolumn{7}{l}{} \\
\cline { 2 - 7 } Population & DBH & BD & PPY & FL & MFA & CC & S/ha \\
\hline Complete & 21.02 & 493.09 & 50.97 & 0.74 & 18.04 & 41.78 & 0 \\
Selected & 21.91 & 532.22 & 51.00 & 0.75 & 17.76 & 42.19 & 1270.62 \\
Absolute & $0.89^{\mathrm{a}}$ & $39.13^{\mathrm{a}}$ & 0.03 & 0.01 & -0.28 & 0.41 & $1270.62^{\mathrm{a}}$ \\
gain & & & & & & & \\
\hline
\end{tabular}

${ }^{a}$ Gain is statistically significant $(\mathrm{P}<0.05)$

diameter and marginal changes on all other traits. Considering the economic objective, the predicted profit is significant with an additional $\$ 1270.62$ per ha obtained above using the average of the population under study. Figure 2 shows that the selected trees (triangles) are mostly in the centre of the distributions of PPY, FL, MFA and CC, confirming the minor changes on the average of those traits.

\section{Conclusions}

The economics of plantations and forest products depend on the combination of multiple traits. Initial selection in most breeding programs has focused on a single trait (usually growth) or a small number of traits without regard for wood properties. Current selection on $\mathrm{DBH}$ and $\mathrm{BD}$ resulted in marginal changes in other traits for which there is significant genetic variation. Including other wood properties in profit calculation will likely change the trees used for breeding. Profit due to changes of FL, MFA and CC will need to be ascertained to study the impact of changes on these traits on the economics of wood processing.

The significant subrace effects for BD, FL and CC was not only reflected on individual traits, but it also affected the relative profitability of the subraces with respect to the base population mean. On average, the most profitable subraces (on NPV/ha over the base population mean) were Strzelecki Ranges (\$862.04), Western Otways (\$657.80) and Strzelecki Foothills (\$576.81). Therefore, careful selection of subraces (and potentially even collection sites within subrace) will improve profit with little, if any, additional cost.

Despite changes in sampling methods and estimation of wood properties, small sample size remains an issue for the estimation of genetic parameters, especially genetic correlations. If confirmed, the lack of significant correlations amongst growth and most wood properties will facilitate tailoring selection towards alternative objectives without major loss of growth productivity. The reported genetic parameters should ideally be confirmed with a larger sample size and in a controlled pollination situation.

\section{Acknowledgments}

Many thanks to Brad Potts, Bruce Greaves, Matthew HamiLton (School of Plant Science, University of Tasmania and CRC for Sustainable Production Forestry, Australia) and Nuno BorRalHo (RAIZ, Portugal) for comments on the manuscript and access to bibliographical material.

\section{References}

ApIOLAZA, L. A. and D. J. GARRICK (2001): Breeding objectives for three silvicultural regimes of radiata pine. Can. J. For. Res. 31: 654-662.

ApiolazA, L. A. and B. L. Greaves (2001): Why are most breeders not using economic breeding objectives? P. In: IUFRO Conference Developing the Eucalypt of the Future, Valdivia, Chile.

Bannister, M. H. (1959): Artificial selection and Pinus radiata. NZ J. Forest. 8: 69-90.

Bootle, K. R. (1983): Wood in Australia: types, properties, uses. McGraw-Hill, Sydney.

BorRalHo, N. M. G. (1994): Heterogeneous selfing rates and dominance effects in estimating heritabilities from open-pollinated progeny. Can. J. For. Res. 24: 1079-1082.

Borralho, N. M. G., P. P. Cotterill and P. J. Kanowski (1993): Breeding objectives for pulp production of Eucalyptus globulus under different industrial cost structures. Can. J. For. Res. 23: 648-656.

Doughty, R. W. (2000): A natural and commercial history of the gum tree. The John Hopkins University Press, London.

Dutkowski, G. W., A. R. Gilmour and N. M. G. Borralho (2001): Modification of the additive relationship matrix for open pollinated trials. P. CD-ROM communication. In: Developing the Eucalypt of the Future, Valdivia, Chile. 10-15 September, 2001.

Dutkowski, G. W. and B. M. PotTs (1999): Geographic patterns of genetic variation in Eucalyptus globulus ssp. globulus and a revised racial classification. Australian Journal of Botany 47: 237-263.

Evans, R., S. Stringer and R. P. KibBlewhite (2000): Variation of microfibral angle, density and fibre orientation in twenty-nine Eucalyptus nitens trees. Appita J. 53: $450-457$.

Gilmour, A. R., B. R. Cullis, S. J. Welham and R. ThompSON (2002): ASReml reference manual. New South Wales Agriculture.

GODDARD, M. E. (1998): Consensus and debate in the definition of breeding objectives. J. Dairy Sci. 81: 6-18.

GREAVES, B. L., N. M. G. BorRalHo and C. A. RAYMOND (1997): Breeding objective for plantation eucalypts grown for production of kraft pulp. For. Sci. 43: $465-472$.

Hardner, C. M., R. E. Vaillancourt and B. M. Potts (1996): Stand density influences outcrossing rate and growth of open-pollinated families of Eucalyptus globulus. Silvae Genet. 45: 226-228.

HAZEL, L. N. (1943): The genetic basis for constructing selection indexes. Genetics 28: 476-490.

Kerr, R. J., G. W. DutKowski, L. A. Apiolaza, T. A. McRae and B. TIER (2002): Developing a genetic evaluation system for tree breeding - the making of TREEPLAN ${ }^{\circledR}$. P. CD-ROM Communication $\mathrm{n}^{\circ} 22-02$. In: $7^{\text {th }}$ World 
Congress of Genetics Applied to Livestock Production, Montpellier, France. 19-23 August, 2002.

Kube, P. D., C. A. Raymond and P. W. Banham (2001): Genetic parameters for diameter, basic density, fibre properties and cellulose content for Eucalyptus nitens. Forest Genet. 8: 285-294.

MacDonald, A. C., N. M. G. Borralho and B. M. Potts (1997): Genetic variation for growth and wood density in Eucalyptus globulus ssp. globulus in Tasmania (Australia). Silvae Genet. 46: 236-241.

Miranda, I., M. H. Almeida and H. Pereira (2001a): Influence of provenance, subspecies, and site on wood density in Eucalyptus globulus Labill. Wood and Fiber Science 33: 9-15.

Miranda, I., M. H. Almeida and H. Pereira (2001b): Variation of fibre biometry in different provenances of Eucalyptus globulus Labill. Appita J. 54: 272-280.

MuneRI, A. and C. A. RAYMOND (2000): Genetic parameters and genotype-by-environment interactions for basic density, pilodyn penetration and diameter in Eucalyptus globulus. Forest Genet. 7: 321-332.

PonZONI, R. W. (1986): A profit equation for the definition of the breeding objective of Australian merino sheep. J. Anim. Breed. Genet. 103: 342-357.

Potts, B. M., G. W. DutKowski, G. J. Jordan and R. E. VAILLANCOURT (1999): Providing a population genetic framework for exploitation of eucalypt genetic resources: The case of Eucalyptus globulus. P. 97-101. In: Australian Plant Breeding Conference, Adelaide, South Australia. 19-23 April.

Potts, B. M., R. E. Vaillancourt, G. J. Jordan, G. W. Dutkowski, J. Costa E Silva, G. McKinnon, D. A. Steane, P. W. Volker, G. A. Lopez, L. A. Apiolaza, Y. Li, C. Marques and N. M. G. Borralho (2004): Exploration of the Eucalyptus globulus gene pool. P. In: Eucalyptus in a changing world, Aveiro, Portugal. 11-15 October.

Potts, B. M., P. W. Volker, G. R. Hodge, N. M. G. BorRALHo, C. M. HARDNER and J. V. OWEN (1995): Genetic limitations in the exploitation of base populations of Eucalyptus globulus spp. globulus. P. 217-221. In: Eucalypt plantations: improving fibre yield and quality, Hobart, Tasmania, Australia. 19-24 February 1995.

RAYMOND, C. A. and L. A. ApIOLAZA (2004): Incorporating wood quality and deployment traits in Eucalyptus globulus and Eucalyptus nitens. In: 'Plantation Forest Biotechnology for the $21^{\text {st }}$ Century'. (Ed. C. WALTER and M. J. CARSON.) pp. 87-99. Research Signpost, Kerala.

RAYmond, C. A. and L. R. SCHIMLECK (2002): Development of near infrared reflectance analysis calibrations for estimating genetic parameters for cellulose content in Eucalyptus globulus. Can. J. For. Res. 32: 170-176.

Thulin, I. J. (1957): Application of tree breeding to forestry in New Zealand. NZ J. Forest. 7: 41-46.

\title{
Early Assessment of First Year Height Data from Five Acacia mearnsii (black wattle) Sub-populations in South Africa using REML/BLUP
}

\author{
By R. W. Dunlop ${ }^{1)}$, M. D. V. Resende ${ }^{2)}$ and S. L. BeCK ${ }^{1, *}$ )
}

(Received $15^{\text {th }}$ November 2004)

\begin{abstract}
Recent research has shown, Acacia mearnsii (black wattle) to be a source of high quality pulp. This led to a change in the emphasis in the breeding programme at the Institute for Commercial Forestry Research, from improving bark yield and quality, to improving timber yield and quality while maintaining an acceptable bark quality. A Multiple Population Breeding Strategy was implemented to cater for these changes. Five sub-populations were established across different sites in KwaZulu-Natal and were determined by origin of seed. Each sub-population was established as a progeny trial with a seedling seed orchard adjacent to it. The management of the seed orchards will be determined according to the performance of the families within the progeny trials. This paper reports on the first year height measurements taken from the five sub-populations. The inten-

\footnotetext{
$\overline{1) \text { Institute }}$ for Commercial Forestry Research, P.O. Box 100281, Scottsville, Pietermaritzburg 3209, South Africa.

2) Embrapa Florestas, Ministry of Agriculture - National Center for Forestry Research Caixa Postal 319, CEP 83411-000, Colombo, PR, Brazil.

*) Author for correspondence. E-mail: Sascha@icfr.unp.ac.za
}

tion of this paper is not to base any selections from this data but rather to establish a set of analyses using REML/BLUP which will be used for future data analysis. This will also allow for future assessment of age-age correlations for the various traits being assessed and provide an appropriate decision-making tool, for selecting individuals for future generations.

Key words: Acacia mearnsii, black wattle, BLUP, height measurements, REML, sub-populations.

\section{Introduction}

Acacia mearnsii (black wattle) was reportedly first introduced to South Africa in 1864. About ten years later the first wattle plantations were established, primarily for firewood, shelterbelts and shade for livestock (SHERRY, 1971). Early tanning tests carried out in South Africa, in 1884, indicated that the bark from black wattle was rich in vegetable tannins that could be used in the leather tanning industry. This led to widespread planting of black wattle with the greatest success in KwaZulu-Natal (JARMAIN and LLOYD JONES, 1982). The black wattle industry in South Africa, peaked in the 